\title{
Differential Effect Of The Sarbanes-Oxley Act On Individual And Institutional Investors
}

\author{
Sorah Park, Ewha Womans University, Korea
}

\begin{abstract}
This study investigates the differential effect of the Sarbanes-Oxley Act of 2002 ("SOX") on unsophisticated individual investors and sophisticated institutional investors. I examine the relationship between abnormal stock returns around quarterly earnings announcements before and after SOX and investor sophistication. Empirical test results show that SOX positively affected stock returns reaction around the quarterly earnings announcement, consistent with prior literature. However, the increased stock returns reaction in the post-SOX period appears to be unrelated to individual investors. I find that the impact of SOX on institutional investor reaction to earnings announcement is statistically significant, whereas individual investor reaction to earnings announcement is not affected by SOX. This suggests that institutional investors have improved on the extent to which earnings information is efficiently priced after SOX, but not individual investors. These findings are important because the differential effect of the accounting disclosure regulation on investors has received little attention in the literature.
\end{abstract}

Keywords: The Sarbanes-Oxley Act of 2002; Investor Sophistication; Individual Investors; Institutional Investors

\section{INTRODUCTION}

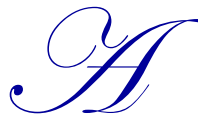
number of major corporate and accounting scandals including those affecting Enron, Tyco International, Adelphia and WorldCom cost investors billions of dollars when the share prices of the affected companies collapsed and shook public confidence in the nation's securities markets. These scandals encouraged lawmakers to reform corporate and accounting regulations.

The Sarbanes-Oxley Act of 2002, also known as the Public Company Accounting Reform and Investor Protection Act of 2002 and commonly called SOX, is a United States federal law enacted on July 30, 2002 in response to these scandals. The Act establishes the new corporate and accounting reform law that changes the way publicly traded companies prepare their financial reports, transforms how the audits are conducted, and increases civil and criminal penalties for violations of securities laws and applicable rules and regulations.

High profile business failures, well-publicized financial restatements and audit failures which incurred before the Act had caused erosion in investor confidence and had made the market participants wary of the possibility of increased adverse selection costs in all equities - big or small. Jain, Kim and Rezaee (2008) suggest that the public information provided by the larger companies becomes questionable and the market participants face a heightened risk of trading against some privately informed insiders and thus incurring losses in their trades.

Since the aim of SOX is to produce more accurate and more reliable financial statements, the importance of understanding and interpreting accounting information and its effect on pricing has increased. Moreover, there is evidence that pricing is affected by investor sophistication. Hand (1990) provides evidence consistent with the extended functional fixation hypothesis (EFFH), which posits that a firm's stock price is sometimes set by marginal investors who are relatively sophisticated in their understanding and interpretation of accounting data, while at other times the price is set by unsophisticated marginal investors who are less knowledgeable about the properties of accrual accounting. Thus, the EFFH implies that when investors respond to earnings signals comprised of cash flow and accrual components, there is a greater likelihood that a security can be temporarily mispriced when the price is 
set by unsophisticated marginal investors and a smaller likelihood that a security can be temporarily mispriced when it is priced by sophisticated marginal investors.

This study investigates the differential impact of SOX on individual and institutional investors by examining the relationship between abnormal returns before and after SOX and investor sophistication. Stock returns reaction to the quarterly earnings announcements is important in showing the changes between pre-SOX and post-SOX periods. Specifically, I calculate the percentage of cumulative abnormal returns that occur around quarterly earnings announcement (called "Reaction Ratio"), following Smith (2008). Also, institutional holdings are used as a valid proxy for investor sophistication, as in Bartov, Radhakrishnan and Krinsky (2000).

The stated objective of SOX is "to protect investors by improving the accuracy and reliability of corporate disclosures made pursuant to the securities laws." Since individual investors are less informed than institutional investors and do little analysis on their own prior to earnings announcements, I conjecture that SOX will protect unsophisticated investors to a greater extent compared to sophisticated investors if SOX served its purpose. Then, unsophisticated investors will revise their earnings expectations more during the announcement period and exhibit higher reaction ratios than sophisticated investors.

Empirical analysis results show that SOX positively affected stock returns reaction around the quarterly earnings announcement, consistent with prior literature (e.g., Li, Pincus and Rego, 2008). However, contrary to my prediction, the nature of the analysis does not provide conclusive evidence whether the increase of stock returns reaction in the post-SOX period is mainly caused by individual investors. I find that the impact of SOX on institutional investor reaction to earnings announcement is statistically significant, whereas individual investor reaction to earnings announcement is not affected by SOX. This evidence indicates that institutional investors have improved on the extent to which earnings information is efficiently priced after SOX, but not individual investors.

These findings contribute to the literature in two ways. First, I shed light on the effects of SOX on investor sophistication. This is important because they point to the differential effect of the accounting regulation on investor groups, which has received little attention in the SOX literature. Policy makers may find this result useful in assessing the benefits and costs of the specific regulation. Second, this study employs a new measure of earnings usefulness developed by Smith (2008) in order to compare the stock returns reaction to earnings announcement before and after SOX. Focusing on how immediate the investor revision takes place during the announcement period provides new perspectives on the effect of SOX on the usefulness of earnings announcement.

The remainder of this paper is organized as follows. Section II develops the hypothesis and summarizes its empirical implications. Section III outlines the sample selection procedure, defines the variables, and describes the data. Section IV discusses the tests and reports the results. The final section offers concluding remarks.

\section{MOTIVATION \& HYPOTHESES DEVELOPMENT}

The costs and benefits of the Sarbanes-Oxley Act have been profoundly discussed in the literature since its passage. The stated objective of the Act is to improve the accuracy and reliability of corporate disclosures, particularly annual and quarterly financial statements. Evidence from several recent studies seems to suggest that the Act has achieved this particular goal. Rezaee and Jain (2005) find evidence indicating that SOX has encouraged management of affected companies to become more conservative in their public financial reports. The investors should view such a change towards a more objective, transparent, reliable, and conservative reporting favorably. Moreover, Rezaee and Jain (2005) find that the market reacted positively to the passage of SOX. Results in Jain, Kim and Rezaee (2008) suggest that there is an increase in investor confidence after the passage of SOX. Additionally, the extent of earnings management decreased after the passage of SOX (Cohen, Dey and Lys, 2008). However, Lobo and Zhou (2006) find that accounting earnings are slower in reflecting good news after SOX.

Smith (2008) introduces to the literature a different returns-based measure of earnings usefulness and shows that there has been a substantial increase in usefulness in recent years. Furthermore, he provides empirical evidence showing that the usefulness of earnings announcements increased significantly after SOX. 
The development of my hypotheses adopts some of the assumptions contained in prior empirical and analytical work. Similar to Hand (1990) and Kim and Verrecchia (1994), I assume that there are two types of investors. Some market participants are sophisticated investors who are experts in gathering and processing public information. Conversely, other investors are unsophisticated; they primarily use information in the financial press and intuition rather than performing rigorous analysis of financial statements (Bartov, Radhakrishnan and Krisnky, 2000). I also assume that sophisticated investors are able to characterize the autoregressive nature of the process underlying earnings and to unbiasedly estimate its parameters. Conversely, unsophisticated retail investors are assumed to perceive the process to be a seasonal random walk. Therefore, stock prices reflect a weighted average of all investors' assessments of a firm's future prospects and value (Bartov, Radhakrishnan and Krisnky, 2000).

The idea that security prices are influenced by the trading activities of both sophisticated and unsophisticated investors provides a testable prediction about the cross-sectional variation in abnormal stock returns around earnings announcement. First, if SOX increased the reliability of quarterly earnings announcements, then I expect stock returns reaction during the announcement period to be more pronounced in the post-SOX period than in the preSOX period. Second, I predict the effect of SOX will be different depending on investor sophistication. Specifically, stock returns reaction during the announcement period is expected to be greater for stocks held primarily by institutional investors than those held by individual investors in the post-SOX period, if sophisticated investors revise their earnings expectations more promptly during the announcement period after SOX.

\section{DATA \& METHODOLOGY}

\subsection{Sample Selection}

The final sample includes 47,195 firm-quarter observations from the first quarter of 1997 to the first quarter of 2007 for NYSE/AMEX firms. The sample period is restricted to 1997 2007 in order to have 5-year data before and after the Sarbanes-Oxley Act of 2002 for comparison purposes.

Table 1 shows the criteria used to select the sample. First, I require that the quarterly earnings announcement dates be available on the quarterly Compustat database from 1997 to 2007. This allows me to calculate the cumulative abnormal returns around the earnings announcement days. Also, I delete if 1) earnings per share for the quarter to which the earnings announcement belongs; 2) the closing share price at the beginning of the fiscal year to which the earnings announcement belongs; 3 ) the price at the end of each quarter to which the event belongs; 4) the number of common shares traded during the event quarter is missing on the quarterly Compustat database; or 5) total assets are missing on the quarterly Compustat database. These criteria yield 233,949 firm-quarter observations covering 10,919 distinct firms.

Second, I require that daily returns and size-adjusted returns be available from the first quarter of 1997 to the first quarter of 2007 on the Center for Research in Security Prices (CRSP) database in order to calculate the cumulative abnormal returns around the quarterly earnings announcement dates. This requirement reduces my sample size to 53,198 firm-quarters, representing 1,298 distinct firms.

Third, I obtain the institutional holding data for each firm-quarter observation meeting the first two data requirements from the Thompson Financial Ownership data. The number of shares held by institutions at the end of each calendar quarter immediately preceding the quarterly earnings announcement based on Section 13(f) filings and the number of shares outstanding at the end of each calendar quarter are collected. This criterion yields 47,431 firm-quarters covering 1,291 distinct firms.

Finally, I delete 0.25 percent extreme observations from each tail based on the Reaction Ratio variable (defined in the following section). The final sample consists of 47,195 firm-quarter observations (1,291 distinct firms). 
Table 1. Sample Selection

\begin{tabular}{|c|c|c|}
\hline & No of Observations & No of Distinct Firms \\
\hline Firm-quarters available on Compustat and in NYSE/AMEX ${ }^{\text {a }}$ & 233,949 & 10,919 \\
\hline Less: No 10-year CRSP data ${ }^{b}$ & $(180,751)$ & $(9,621)$ \\
\hline Less: No institutional holdings data ${ }^{c}$ & $(5,767)$ & (7) \\
\hline Less: Outliers ${ }^{\mathrm{d}}$ & $(236)$ & $(0)$ \\
\hline Final sample & 47,195 & 1,291 \\
\hline \multicolumn{3}{|c|}{$\begin{array}{l}\text { a Sample firms are required to have (1) earnings announcement dates, trading volume, total assets, earning per share in the quarterly Compustat } \\
\text { and (2) belong to NYSE/AMEX exchanges. } \\
\text { b Observations with missing CRSP data on raw daily returns or size-deciles from the first quarter of } 1997 \text { to the first quarter of } 2007 \text { are } \\
\text { eliminated from the sample. } \\
\text { c Observations without institutional holdings data on the Thompson Financial database are eliminated. } \\
\text { d Observations in the } 0.25 \text { percent extreme tails of the distributions of } R R \text { (Reaction Ratio) are eliminated. RR }=\operatorname{CAR}[-2,+1] / \text { CAR }[-2,+60] \text {. } \\
\text { CAR }[-2,+1] \text { is daily abnormal returns cumulated over three days }(-2,-1,0,+1) \text { and CAR }[-2,+60] \text { is daily abnormal returns cumulated over day - } \\
2 \sim+60 \text {, where day } 0 \text { is the earnings announcement date. }\end{array}$} \\
\hline
\end{tabular}

\subsection{Measurement of Stock Returns Reaction Ratio}

The stock returns reaction ratio is measured using the cumulative abnormal returns for each firm-quarter observation. The daily abnormal return for firm $i$ on day $t$ is computed as below:

$$
A R_{i t}=R E T_{i t}-D E C R E T_{i t}
$$

where, $R E T_{i t}$ is the daily return of firm $i$ on day $t$ and $D E C R E T_{i t}$ is the equally-weighted average returns on day $t$ for NYSE/AMEX firms in the same size-decile based on January 1 market values.

Next, the Reaction Ratio $\left(R R_{i q}\right)$ is defined as the ratio of cumulative abnormal returns measured over [-2,+1] and cumulative abnormal returns measured over $[-2,+60]$ where day 0 is the quarterly earnings announcement date.

$$
\mathrm{RR}_{\mathrm{iq}}=\frac{C A R_{i q}[-2,+1]}{C A R_{i q}[-2,+60]}
$$

where, $C A R_{i q}[-2,+1]$ denotes the sum of daily abnormal returns of firm $i$ for the four trading day period $(\mathrm{t}=-2,-1$, $0,+1)$, and $C A R_{i q}[-2,+60]$ denotes daily abnormal returns of firm $i$ cumulated over 62 trading-day interval [-2, $+60]$, where 0 represents the earnings announcement date of quarter $q$ from Compustat.

\subsection{Proxy for Investor Sophistication}

Institutional investor holdings of a stock have been widely used as a proxy for investor sophistication in prior literature (e.g., Hand, 1990; Utama and Cready, 1997; Walther, 1997; El-Gazzar, 1998; Bartov, Radhakrishnan and Krisnky, 2000). This is a suitable proxy because institutional investors have a relative advantage in gathering and processing information. Moreover, the institutional holdings are readily available for a large number of firms.

Bartov, Radhakrishnan and Krisnky (2000) show the institutional holdings variable is important in explaining the stock-price responses to earnings announcements and post-earnings announcement drifts. More specifically, the institutional investors improve on the earnings-processing problems that cause post-earnings-announcement drift and increase the degree to which earnings information is efficiently priced.

The institutional investor holdings for firm $i$ in quarter $q\left(I H_{i q}\right)$ is computed as the proportion of common shares outstanding held by institutional investors. We follow prior research (e.g. Hand, 1990; Bartov et al., 2000) by dividing the number of common shares held by institutional investors at the end of the quarter just prior to each earnings announcement by the number of common shares outstanding on that date. 


\subsection{Test Model}

I estimate the following regression equation for the full sample to examine my first hypothesis. Next, in order to examine the second hypothesis, I estimate the following regression model for two sub-samples: (1) stocks largely held by unsophisticated individual investors and (2) stocks largely held by sophisticated institutional investors.

$$
R R_{i q}=\beta_{0}+\beta_{1} S O X_{i q}+\beta_{2} S U R P R I S E_{i q}+\beta_{3} S I Z E_{i q}+\beta_{4} V O L_{i q}+\beta_{5} P R C_{i q}+\varepsilon_{i q}
$$

where, $R R_{i q}$ is the stock returns reaction ratio for firm $i$ and quarter $q$ and $S O X_{i q}$ is the dummy variable that is set to 1 if the earnings announcement date of quarter $q$ is after SOX is implemented (i.e. after July 31 2002), and 0 if the earnings announcement was made before July 312002.

I include several control variables in the model. First, prior research on the post-earnings-announcement drift (e.g. Bernard and Thomas, 1990; Bartov, 1992; Ball and Bartov, 1996) has shown that the unexpected earnings have significant impact on the abnormal returns. Earnings surprise (SURPRISE), which is calculated as the earnings per share for the quarter less the earnings per share of the corresponding quarter in the previous year (scaled by the price), is included to control for the effect of unexpected earnings. Second, the size of firm $i$ associated with the earnings announcement of quarter $q$ is measured by the natural logarithm of total assets (SIZE). Third, the trading volume $(V O L)$ of firm $i$ associated with the earnings announcement of quarter $q$ is measured over the fiscal year preceding the year to which quarter $q$ belongs. Lastly, $P R C_{i q}$ is the closing price of firm $i$ 's common shares associated with the earnings announcement of quarter $q$ measured at the beginning of the fiscal year $t$ to which quarter $q$ belongs.

\section{TESTS AND RESULTS}

\subsection{Description of The Sample}

Panel A of Table 2 provides summary statistics for the full sample and Panel B and Panel C provide summary statistics for the individual investors sub-sample and the institutional investors sub-sample. Since I require that firms survive ten consecutive years, my (full) sample firms tend to be larger and more successful. The mean and median of firm size (SIZE) are 4.0020 and 2.9367, respectively. Earnings surprise (SURPRISE) has positive mean (0.0004) and median (0.001). The mean (median) institutional holdings $(I H)$ in full sample are $53 \%(56 \%)$.

In Panel $\mathrm{B}$ and $\mathrm{C}$, the mean (median) $I H$ of retail investors sub-sample and institutional investors sub-sample are $30 \%(31 \%)$ and $76 \%(75 \%)$, respectively. SIZE, VOL, and PRC tend to be larger for institutional investors subsample than for individual investors sub-sample, whereas the institutional investors sub-sample has smaller earnings surprise (SURPRISE) than individual investors sub-sample. 
Table 2. Summary Statistics

\begin{tabular}{|c|c|c|c|c|c|}
\hline \multicolumn{6}{|c|}{ Panel A: Full sample $(n=47,195)$} \\
\hline & $25^{\text {th }}$ Percentile & Mean & Median & $75^{\text {th }}$ percentile & Std dev \\
\hline $\mathrm{RR}^{\mathrm{a}}$ & -0.15 & 0.20 & 0.14 & 0.49 & 3.01 \\
\hline $\mathrm{IH}^{\mathrm{b}}$ & 0.31 & 0.53 & 0.56 & 0.75 & 0.27 \\
\hline SURPRISE $^{\mathrm{c}}$ & -0.005 & 0.0004 & 0.001 & 0.005 & 0.11 \\
\hline SIZE (million\$) ${ }^{\mathrm{d}}$ & 2.364 & 4.002 & 2.937 & 3.563 & 4.792 \\
\hline VOL (million) ${ }^{\mathrm{e}}$ & 2.24 & 46.19 & 9.89 & 36.50 & 145.82 \\
\hline $\operatorname{PRC}(\$)^{f}$ & 11.56 & 27.94 & 22.93 & 37.36 & 32.20 \\
\hline
\end{tabular}

Panel B: Individual investors sample $(\mathrm{n}=\mathbf{2 3 , 5 9 7 )}$

\begin{tabular}{|c|c|c|c|c|c|}
\hline & $25^{\text {th }}$ Percentile & Mean & Median & $75^{\text {th }}$ percentile & Std dev \\
\hline RR & -0.14 & 0.19 & 0.12 & 0.44 & 2.89 \\
\hline $\mathrm{IH}$ & 0.16 & 0.30 & 0.31 & 0.44 & 0.16 \\
\hline SURPRISE & -0.006 & 0.0008 & 0.0008 & 0.006 & 0.14 \\
\hline SIZE (million\$) & 1.924 & 3.726 & 2.581 & 3.238 & 4.529 \\
\hline VOL (million) & 0.91 & 25.84 & 2.98 & 10.51 & 153.76 \\
\hline $\operatorname{PRC}(\$)$ & 6.49 & 20.13 & 15.60 & 27.75 & 22.70 \\
\hline
\end{tabular}

Panel C: Institutional investor sample $(n=23,598)$

\begin{tabular}{|c|c|c|c|c|c|}
\hline & $25^{\text {th }}$ Percentile & Mean & Median & $75^{\text {th }}$ percentile & Std dev \\
\hline RR & -0.15 & 0.21 & 0.16 & 0.53 & 3.12 \\
\hline IH & 0.66 & 0.76 & 0.75 & 0.85 & 0.13 \\
\hline SURPRISE & -0.004 & 0.0001 & 0.001 & 0.004 & 0.08 \\
\hline SIZE (million\$) & 2.742 & 4.170 & 3.229 & 3.784 & 4.906 \\
\hline VOL (million) & 9.47 & 66.52 & 25.45 & 65.64 & 134.37 \\
\hline $\operatorname{PRC}(\$)$ & 18.80 & 35.72 & 29.85 & 44.93 & 37.89 \\
\hline
\end{tabular}

${ }^{\mathrm{a}} R R_{i, q}$ is defined as the ratio of $\mathrm{CAR}_{\mathrm{i}, \mathrm{q}}[-2,+1]$ and $\mathrm{CAR}_{\mathrm{i}, q}[-2,+60]$ for firm $\mathrm{i}$ and quarter $\mathrm{q}$.

${ }^{\mathrm{b}} I H_{i, q}$ is the proportion of common shares outstanding held by institutional investors.

${ }^{\mathrm{c}}$ Earnings surprise, SURPRISE $E_{i, q}$, is calculated as the earnings per share for the quarter less the earnings per share of the corresponding quarter in the previous year, scaled by the price.

${ }^{d}$ The size of firm $i$ associated with the earnings announcement of quarter q (SIZE) is measured by the logarithm of total asset.

${ }^{\mathrm{e}}$ The trading volume $(V O L)$ of firm i associated with the earnings announcement of quarter $\mathrm{q}$ is measured over the fiscal year preceding the year to which quarter $\mathrm{q}$ belongs.

${ }^{\mathrm{f}} P R C_{i, t}$ is the closing price of firm i's common share associated with the earnings announcement of quarter $\mathrm{q}$.

\subsection{The Impact of SOX on The Stock Returns Reaction Around The Quarterly Earnings Announcements}

Table 3 reports the OLS (ordinary least squares) coefficient estimates for two regression models. Panel A is the result for Equation (3) with SOX dummy (1 if after the Sarbanes-Oxley act has been effective; i.e., August, 2002) as only an explanatory variable. As expected, in the full sample, the coefficient estimate on $S O X$ is positive and statistically significant $(0.08, t$-stat $=2.90)$. The stock returns reaction to the quarterly earnings announcements, which is measured by Reaction Ratio, became significantly larger after SOX. This implies that investors revise their expectations more promptly during earnings announcement periods than non-announcement periods after SOX.

Panel B of Table 3 reports the OLS results of Equation (3) including the control variables-- earnings surprise, firm size, trading volume, and stock price-- which can potentially affect the stock returns response during earnings announcement periods. All the coefficients on these controls are insignificant. The result regarding to SOX is still significant after controlling $(0.09, t$-stat $=3.06)$. This finding is consistent with those in Smith $(2008)$ in that the usefulness of earnings announcement increased after the implementation of SOX.

My first set of test results suggests that the overall market reacts more promptly to the quarterly earnings announcements during the announcement period after SOX. Since equity price adjustments are made more immediately around the announcements after SOX, the usefulness of earnings announcements has increased due to SOX. 
In the next sections, I investigate whether both individual investors and institutional investors contribute to the increased reaction ratio. Specifically, I examine which investors revise expectations more immediately during the earnings announcement periods after SOX: individual investors or institutional investors.

Table 3. SOX and Stock Returns Reaction around the Earnings Announcement (Full sample; $n=47,195)$

\begin{tabular}{|c|c|c|c|c|}
\hline \multicolumn{5}{|c|}{ Panel A: SOX and stock return reaction around the earnings announcement } \\
\hline \multicolumn{5}{|c|}{ Model 1: $R R_{i, q}=\beta_{0}+\beta_{1} \cdot S O X_{i, q}+$ error $_{i, q}$} \\
\hline & Predicted sign & Coefficient & t-statistic & p-value \\
\hline Intercept & & 0.16 & $8.56^{* * *}$ & $<0.0001$ \\
\hline SOX & + & 0.08 & $2.90 * * *$ & 0.0037 \\
\hline
\end{tabular}

Panel B: SOX and stock return reaction around the earnings announcement, controlling for earnings surprise, firm size, trade volume, and stock price

\begin{tabular}{l|c|c|c|c}
\hline Model 2: $R R_{i, q}=\beta_{0}+\beta_{1} \cdot$ SOX $_{i, q}+\beta_{2} \cdot$ SURPRISE $_{i, q}+\beta_{3} \cdot$ SIZE $_{i, q}+\beta_{4} \cdot$ VOL $_{i, q}+\beta_{5} \cdot P R C_{i, q}+$ error $_{i, q}$ \\
\hline & Predicted sign & Coefficient & t-statistic & p-value \\
\hline Intercept & & 0.16 & $7.27 * * *$ & $<0.0001$ \\
\hline SOX & + & 0.09 & $3.06 * * *$ & 0.0022 \\
\hline SURPRISE & + & 0.03 & 0.23 & 0.8220 \\
\hline SIZE & - & 0.00 & -0.51 & 0.6077 \\
\hline VOL & - & 0.00 & -1.19 & 0.2346 \\
\hline PRC & - & 0.00 & 0.33 & 0.7451 \\
\hline
\end{tabular}

Note: $* * *$ indicates that the coefficient is statistically significant at $1 \%$ level.

\subsection{The Impact of SOX on Individual Investor Reaction to The Earnings Announcement}

In this section, I report the OLS regression results for the sub-sample consisting of stocks largely held by individual investors. Following prior literature (e.g., Hand, 1990), I use institutional holdings as a proxy for investor sophistication. Since the stock price reflects a weighted average of sophisticated and unsophisticated investors' expectations, the greater the involvement of sophisticated investors in a stock the greater their influence on the price. Thus, by selecting observations with less than the median institutional holdings $(I H)$, this sub-sample consists of the stocks largely held by unsophisticated individual investors. Out of 47,195 firm-quarter observations, I select 23,597 observations with less than the median $I H$ of the full sample.

Panel A of Table 4 presents the results for the OLS regression of individual investor Reaction Ratio on SOX. Contrary to my second hypothesis, the coefficient on $S O X$ is insignificant $(0.06, t$-stat $=1.57)$. This suggests that individual investors did not change their reactions to the quarterly earnings announcements when SOX was implemented. In other words, individual investors do not revise their earnings expectations more promptly during the announcement periods after SOX. Panel B of Table 4 also reports the insignificant coefficient on $S O X(0.06, t$ stat $=1.59$ ) and insignificant coefficients on all the control variables. This sub-sample result implies that individual investors are not the ones who contribute to the increased Reaction Ratio after SOX shown in the previous section. Thus, the implementation of SOX did not induce a faster revision of expectation of individual investors.

A possible explanation for the insignificant relation between individual investor Reaction Ratio and SOX is that unsophisticated individual investors may not be fully aware of the indirect evidence of the improved information quality of earnings after SOX, ${ }^{1}$ or they may not be convinced that the accounting disclosure regulation such as SOX improves the disclosure quality so their decision making process, such as earnings expectation revision, is not affected by SOX.

\footnotetext{
${ }^{1}$ Prior research (e.g., Bartov and Cohen, 2007; Beneish et al., 2008; Smith, 2008) provides indirect evidence on the improved information quality of earnings announcements after the passage of SOX.
} 
Table 4. Individual Investors, SOX and Stock Return Reaction around the Earnings Announcement $(\mathrm{n}=23,597)$

\begin{tabular}{|c|c|c|c|c|}
\hline \multicolumn{5}{|c|}{ Panel A: Individual investors, SOX and stock return reaction } \\
\hline \multicolumn{5}{|c|}{ Model 1: $R R_{i, q}=\beta_{0}+\beta_{1} \cdot S_{S O X_{i, q}}+$ error $_{i, q}$} \\
\hline & Predicted sign & Coefficient & t-statistic & p-value \\
\hline Intercept & & 0.17 & $7.18 * * *$ & $<0.0001$ \\
\hline SOX & + & 0.06 & 1.57 & 0.1166 \\
\hline
\end{tabular}

Panel B: Individual investors, SOX and stock return reaction, controlling for earnings surprise, firm size, trade volume, and stock price

\begin{tabular}{|c|c|c|c|c|}
\hline & Predicted sign & Coefficient & t-statistic & p-value \\
\hline Intercept & & 0.16 & $5.38 * * *$ & $<0.0001$ \\
\hline SOX & + & 0.06 & 1.59 & 0.1127 \\
\hline SURPRISE & + & 0.10 & 0.76 & 0.4499 \\
\hline SIZE & - & 0.00 & 0.38 & 0.7023 \\
\hline VOL & - & -0.00 & -0.21 & 0.8304 \\
\hline PRC & - & 0.00 & 0.66 & 0.5100 \\
\hline
\end{tabular}

Note: $* * *$ indicates that the coefficient is statistically significant at $1 \%$ level.

\subsection{The Impact of SOX on Institutional Investor Reaction to The Earnings Announcement}

Table 5 reports the OLS coefficient estimates for the regression based on the institutional investors sub-sample. This sub-sample consists of 23,598 observations out of 47,195 observations with institutional holdings greater than the median of the full sample, representing the stocks largely held by sophisticated institutional investors.

Panel A of Table 5 presents the results for the OLS regression of institutional investor Reaction Ratio on SOX. The coefficient estimate on $S O X$ is significantly positive $(0.10, t$-stat $=2.41)$. This result suggests that institutional investors revise their expectations to a greater extent during earnings announcement periods than non-announcement periods after the Sarbanes-Oxley Act. Panel B of Table 5 also reports the positive and significant coefficient estimate on $\operatorname{SOX}(0.11, t$-stat $=2.73)$ and insignificant coefficients on the control variables.

These findings indicate that institutional investors contribute to the increased Reaction Ratio after SOX. In other words, the full sample result is induced by institutional investors, not by individual investors. This confirms that it is the institutional investors who revise expectation more promptly during the earnings announcement period after SOX. Institutional investors are educated and sophisticated about the effect of SOX on the earnings quality (regardless direct or indirect evidence) so they revise their expectation to a greater extent based on the quarterly earnings announcement after the Sarbanes-Oxley Act. 
Table 5. Institutional Investors, SOX and Stock Return Reaction around the Earnings Announcement $(\mathrm{N}=23,598)$

\begin{tabular}{|c|c|c|c|c|}
\hline \multicolumn{5}{|c|}{ Panel A: Institutional investors, SOX and stock return reaction } \\
\hline \multicolumn{5}{|c|}{ Model 1: $R R_{i, t}=\beta_{0}+\beta_{1} \cdot S O X_{i, t}+$ error $_{i, t}$} \\
\hline & Predicted sign & Coefficient & t-statistic & p-value \\
\hline Intercept & & 0.15 & $4.90 * * *$ & $<0.0001$ \\
\hline SOX & + & 0.10 & $2.41 * *$ & 0.0159 \\
\hline
\end{tabular}

Panel B: Institutional investors, SOX and stock return reaction, controlling for earnings surprise, firm size, trade volume, and stock price

\begin{tabular}{|c|c|c|c|c|}
\hline & Predicted sign & Coefficient & t-statistic & p-value \\
\hline Intercept & & 0.16 & $4.50 * * *$ & $<0.0001$ \\
\hline SOX & + & 0.11 & $2.73 * * *$ & 0.0064 \\
\hline SURPRISE & + & -0.18 & -0.73 & 0.4664 \\
\hline SIZE & - & -0.00 & -0.36 & 0.7221 \\
\hline VOL & - & -0.00 & $-1.86^{*}$ & 0.0633 \\
\hline PRC & - & -0.00 & -0.13 & 0.8984 \\
\hline
\end{tabular}

Note: $* * * * *, *$ indicate that the coefficient is statistically significant at $1 \%, 5 \%, 10 \%$ levels.

\section{CONCLUDING REMARKS}

Did the Sarbanes-Oxley Act affect stock prices? Does the Sarbanes-Oxley Act impact the stock returns reaction to earnings announcement of unsophisticated retail investors? My primary findings show that the enactment of SOX has positively affected the stock returns reaction, but on the other hand such changes due to SOX are not related to unsophisticated individual investors.

My results indicate that stock returns reaction to earnings announcement increased during the period following SOX. This result is expected and consistent with prior literature. In addition to this trend, I investigate whether the impact of SOX is different depending on investor sophistication. The results show that the impact of SOX on institutional investor reaction to earnings announcement is statistically significant but contrarily, individual investor reaction is not influenced by SOX. This evidence means that institutional investors improve on the extent to which earnings information is efficiently priced, but not individual investors.

Readers should be aware of some limitations of this study. The sample period (from 1997 to 2007) is relatively short to assess the effect of regulation on the market participants. Additionally, media coverage of the scandals and the failure of Arthur Andersen during 2002 changed the management's awareness of the issue in advance of the passage of SOX into law on July 30, 2002. Therefore, it may not be entirely valid to treat year -1 as a pre-reform year. Finally, as suggested by Cunningham (2002), the effect of SOX may be mostly psychological rather than economically substantive, although there is no strong evidence supporting such argument.

\section{AUTHOR BIOGRAPHY}

Sorah Park (Corresponding author): Ph.D., Assistant Professor of Accounting at Ewha School of Business, Ewha Womans University, Seoul, Korea.

\section{REFERENCES}

Ball, R., \& Bartov, E. (1996). How Naïve Is the Stock Market's Use of Earnings Information?. Journal of Accounting and Economics, 21(3), 319-337.

Ball, R., \& Brown, P. (1968). An Empirical Evaluation of Accounting Income Numbers. Journal of Accounting Research, 6, 159178.

Bartov, E. (1992). Patterns in Unexpected Earnings As an Explanation for Post-Announcement Drift. The Accounting Review, 67, 610-622.

Bartov, E., \& Cohen, D. (2007). Mechanisms To Meet/Beat Analyst Earnings Expectations in the Pre- and Post-Sarbanes-Oxley Eras. NYU Law and Economics Research Paper No 07-18. 
Bartov, E., \& Mohanram, P. (2004). Private Information, Earnings Manipulations, and Executive Stock-Option Exercises. The Accounting Review, 79, 889-920.

Bartov, E., Radhakrishnan, S., \& Krinsky, I. (2000). Investor Sophistication and Patterns in Stock Returns after Earnings Announcements. The Accounting Review, 75, 43-63.

Beneish, M. D., Billings, M. B., \& Hodder, L. D. (2008). Internal Control Weaknesses and Information Uncertainty. The Accounting Review, 83(3), 665-703.

Bernard, V., \& Jacob, T. (1990). Evidence That Stock Prices Do Not Fully Reflect the Implications of Current Earnings for Future Earnings. Journal of Accounting and Economics, 13, 305-340.

Bushee B. (1998). The Influence of Institutional Investors on Myopic R\&D Investment Behavior. The Accounting Review, 73, 305-333.

Cohen, D. A., Dey, A., \& Lys, T. Z. (2008). Real and Accrual-Based Earnings Management in the Pre- and Post-Sarbanes-Oxley Periods. The Accounting Review, 83(3), 757-787.

El-Gazzar, S. M. (1998). Predisclosure Information and Institutional Ownership: A Cross-Sectional Examination of Market Revaluations during Earnings Announcements Periods. The Accounting Review, 73, 119-129.

Hand, J. R. M. (1990). A Test of the Extended Functional Fixation Hypothesis. The Accounting Review, 65, 740-763.

Jain, P. K., Kim, J. C., \& Rezaee, Z. (2008). The Sarbanes-Oxley Act of 2002 and Market Liquidity. Financial Review, 43(3), 361-382.

Kim, O., \& Verrecchia, R. E. (1994). Market Liquidity and Volume around Earnings Announcements. Journal of Accounting and Economics, 17, 41-67.

Li, H., Pincus, M., \& Rego, S. O. (2008). Market Reaction to Events Surrounding the Sarbanes-Oxley Act Of 2002 and Earnings Management. Journal of Law and Economics, 51(1), 111-134.

Lobo, G. J., \& Zhou, J. (2006). Did Conservatism in Financial Reporting Increase after the Sarbanes-Oxley Act? Initial Evidence. Accounting Horizons, 20 (1), 57-73.

Rezaee, Z., \& Jain, P. K. (2005). The Sarbanes-Oxley Act of 2002 And Security Market Behavior: Early Evidence. Available at SSRN 498083.

Smith, M. (2008). Evidence of a Recent Increase in the Usefulness of Quarterly Earnings Announcements. Working Paper, Boston University.

Utama, S., \& Cready, W. M. (1997). Institutional Ownership, Differential Predisclosure Precision and Trading Volume at Announcements Dates. Journal of Accounting and Economics, 24, 129-150.

Walther, B. (1997). Investor Sophistication and Market Earnings Expectations. Journal of Accounting Research, 35, $157-192$. 